Natacha Rita Díaz-Luis, 2021

Volume 6 Issue 3, pp. 250-268

Date of Publication: 21 ${ }^{\text {st }}$ January 2021

DOI- https://doi.org/10.20319/pijss.2021.63.250268

This paper can be cited as Díaz-Luis, N. R. (2021). E-Learning English as a Foreign Language (EFL) by Means of Using the Journalistic Style. PEOPLE: International Journal of Social Sciences, 6(3), 250-268.

This work is licensed under the Creative Commons Attribution-NonCommercial 4.0 International License. To view a copy of this license, visit http://creativecommons.org/licenses/by-nc/4.0/ or send a letter to Creative Commons, PO Box 1866, Mountain View, CA 94042, USA.

\title{
E-LEARNING ENGLISH AS A FOREIGN LANGUAGE (EFL) BY MEANS OF USING THE JOURNALISTIC STYLE
}

\author{
Natacha Rita Díaz-Luis \\ Faculty of Education, University of La Laguna, Santa Cruz de Tenerife (Canary Islands), Spain \\ alu0100815085@ull.edu.es
}

\begin{abstract}
The journalistic style is a sociocultural phenomenon becoming more common in our reality because of the continuous exposition of media in citizens' experience. This exposition formulates our conception, reinterpretation and construction of the world, as well as it allows us to get to know a great diversity of perspectives among one single concept. Throughout the following journalistic article, the journalistic style has been reconstructed to make students understand and learn new methods of communication regarding the linguistic and communicative norms that media possesses. Moreover, students will be able to learn the different essential features that compose the process of newspaper creation: journalistic article structuration, journalistic cohesion, advertisement production, sections that compose the journalistic piece, etc. Indeed, the aim was to teach and study the digitalization of the English language in a journalist style, thus, using the language in new formats and linguistic contexts. For this study, a group of students belonging to the second year of Secondary Education has been selected. The learning situation was initially based on the comprehension and interpretation of the journalist production of newspapers' productions and eventually, a newspaper was created. Two major skills were developed during the learning of English as a foreign language: reading comprehension and written production. The results obtained were positive: Pupils demonstrated digital structures
\end{abstract}


PEOPLE: International Journal of Social Sciences

ISSN 2454-5899

learning, assimilation of uses of English regarding descriptive and persuasive uses and knowledge about areas and structuration of newspapers.

\section{Keywords}

EFL, Journalistic Article, Newspaper, Persuasive Uses, Vocabulary, Written Production

\section{Introduction}

Mediums of communication have constitutionalized indispensable sources for socialization processes characterized by a high degree of inter-dependable and interconnected individuals. The globalization phenomenon experienced the last decades is generating a new paradigm in the formulation of news production and methodologies to inform individuals. This journalistic environment has caused a high number of resources and informative systems that aim to display data, information and knowledge as immediate as possible.

E-learning is becoming a reality due to the COVID-19 pandemic we are currently living. Thus, our reality is becoming more and more digital regarding jobs, commerce, communication and even education. Newspapers have been being constructed digitally since years ago, although their digital production and consumption has increased due to the global pandemic. Education has also acquired a higher virtual form due to the necessity to reduce the impact of COVID- 19. This has potentiated the introduction of new systems of communication and collaboration using digital tools to keep on the teaching and learning process meanwhile realistic digital realities are taking place, as journalistic productions.

\subsection{What Benefits Offer the use of The Journalistic Style in the Educative Environment?}

Journalism, like many other environments, is an open professional field to apply the English language for different communicative approaches. López (1998) recognized the relevance that mediums of communication have reached in the educational context because of its practical and professional approach. The constitutions of journalistic learning models, as mentioned by López (1998), suggests a pragmatical experience of the learning process of the language using experimentation of this style, analyzing and trying out new methods of communication within the class for the construction of the communicative competence. Undoubtedly, experiencing this new format of the language allows a better comprehension and the formulation of required strategies for linguistic comprehension and production in such contexts. 
Peris (2001) claimed that the introduction of the journalistic style throughout the learning of the English language encourages linguistic knowledge acquisition such as interlocutors' relationship, oral and written texts, the main aim or objective of texts, communicate channels or the degree of privacy or publicity of a text. Both authors (López, 2010; Peris, 2001) analyzed both perspectives from Spanish as a foreign language (SFL), not taking English as the foreign language studied, although these contributions can be considered valid to take them as an educational reference. Reaser (2010) affirmed the necessity to implement linguistic principles in the class using methods like the use of social sciences like sources that contextualize knowledge, taking journalism as a great sample of social science that can be applied for the learning of communication processes.

The learning of a foreign language using a journalistic corpus improves the learning process, not only from a linguistic perspective but also the learning of a standardized and typified language (García Platero, 2000). Gómez (2003) concentrated on the constructions of headlines of newspapers' production in foreign language contexts teaching Spanish as a foreign language; this activity was as an instrument to study written comprehension (newspapers' productions such as journalistic articles, interviews) and small production (title's creation) in contextualized environments of the language. This proposal is characterized by an introduction of the foreign language and construction of strategies in which students must produce from the written comprehension composition. In this sense, there is a communicative application of the English teaching and learning which is eventually assessed by a social task, i.e. communicative testing that evidence students learning because it is meaning-focused, contextualized and due to the creative language output (Hull, 2019). Labarrete (2019) conceives this process as a creative reading approach, in which students make an interaction from the information read to produce their product. Moreover, the appliance of authentic resources of journalism demonstrates learning of cultural and sociolinguistic patrons that fosters the development of oral interactions skills because of the resulting debates generating from what is read (Akdemir et. al., 2012). Oroujlou (2012) recognized that the use of journalism for the learning of EFL encourages language proficiency in students and familiarization with different dialects and linguistic styles. Mittal (2014) has recognized the following advantages due to the utilization of journalistic resources for learning processes:

- Vocabulary learning. 
- Increase in reading rhythm.

- Utilization of daily information refreshed.

- Development of written production and oral comprehension.

- Use of expressions and innovative constructions.

- Learning of uses of English from a practical perspective.

This perception about the learning of the foreign language throughout journalism means a new vision of the learning of a language, not only the foreign but also the mother tongue language. Any language, foreign or native, requires its realistic exposition using real and natural productions of the language to acquire the sociolinguistic and socio-cultural aspects that every language possesses. It has been observed that there is higher learning of new vocabulary by realistic sources than artificial material created for learning purposes (Manasrah et. al., 2014; Shakibaei et al., 2019). Tulloch \& Manchón (2015) also refer to the learning of vocabulary according to the topic of the text in journalistic productions, but they mentioned special importance in their investigation to the application of a great diversity of uses of English when written production is being developed.

\subsection{Research Issue}

The journalistic resources are formulated as pedagogical environments to study that typically develop major conception and tolerance towards the learning of a foreign language (Baumgardner, 1987). The constant exposition to mediums of communications requires to be taking into account to make pupils recognize, analyze and experience new models of communication and a new understanding of different realities among them. Other studies have utilized English as a mother tongue for its study applying journalistic contexts and others using Primary Education as the educational stage for this approach. It has not been hugely investigated about the use of journalistic style for the learning of EFL on Secondary Education. Although authors as Laadem (2017) have investigated the utilization of digital tools in educative contexts affects the academic performance in behavioural aspects, it has been noticed poor investigation among the digital production of journalistic uses of the language in absolutely digitalized circumstances, as well as limited investigations have been developed in Secondary Education stages. For this reason, this research aims to study these aspects and demonstrate the possibilities

of using the journalistic style in digital contexts of learning EFL. The different studies previously mentioned have not been developed in a total virtual context, another important characteristic of 
this investigation. This research aims to analyze a social task entirely developed in a digital platform. Thus, pupils required to use the English language for collaboration and product creation. Moreover, they were asked to consult informational sources in English, select their main ideas and applying them using specific uses of English and vocabulary that will be further mentioned (section of Methodology). In this sense, the aim is to demonstrate the simultaneous learning of written comprehension and production using new uses of English and vocabulary, collaborative and cooperative practices and intercultural learning in a virtual reality of teaching, learning and communicating in Secondary Education.

\section{Methodology}

This section is divided into four different sections that aim to establish the main characteristics of the focus group selected, the main educational methodologies applied, the investigation dynamics and goals that have been chosen and the assessment that has been applied to pupils.

\subsection{The Focus Group}

An empirical study has been proposed by applying a learning situation to observe and analyze, from a practical perspective, the sociolinguistic and sociocultural results obtained from the learning of EFL and producing a newspaper as the final result of the learning situation.

The sample was a small group of students $(n=8)$, belonging to the second year of Secondary Education. These students are enrolled in a private school situated in a semi-urban area (Tenerife, Canary Islands, Spain). This school has a bilingual educational program; thus, students are exposed to EFL from an early age. The learning situation was developed during pandemic circumstances, consequently, face-to-face lessons were cancelled and a fast model of digital learning was adopted in university and non-university institutions. The learning situation was designed according to the learning of uses of English about referring to what someone said (objective references) and revision uses of English about persuasive uses of the English language and events talking about the future. The vocabulary selected is associated with the circumstances that pupils were experiencing: the pandemic. Students needed to apply these two elements (vocabulary and uses of English) for the creation of a newspaper. 


\subsection{Learning Methodologies Used}

Different methodologies have been applied to this social task. Due to the consequence circumstances, the methodologies have been adapted according to the digital atmosphere, and they are summarized in the following lines:

- Cooperative learning. Every pupil adopted a role and its consequence functions to develop the social task. The roles selected were the leader (making sure every pupil is doing his/her part), secretary (taking notes of the most important aspects, organization processes regarding work left to do), speaker (giving feedback on the group's work to the teacher or the class) and time manager (controlling the period selected for the task, organizing the time left to finish the task, looking for strategies to make the group more efficient).

- Task-based learning. By creating a specific task, pupils are employing an authentic use of EFL, as well as the learning is being contextualized. In this sense, the learning of the English language becomes a communicative language teaching (CLT).

- Learning by discovery. As students were asked to check out information which they had to apply for the product creation. In this sense, teacher's guidance has concentrated on the selection of quality sources of information and strategies for its adaptation to their written production.

\subsection{Investigation Dynamic and Goals}

This learning situation and the final result were developed digitally, thus there was an adaption and learning of the English language digitalized. The dynamic employed for this investigation was a focus group $(\mathrm{n}=8)$, as previously mentioned, in which pupils were interviewed daily meanwhile the social task was being produced. The objectives established for this investigation are summarized in the following lines:

- To get to know about the main principles in the process of the journalistic construction of a newspaper. In this sense, $75 \%$ of students recognized poor knowledge about how newspapers are divided and how they are constructed. For this reason, this activity has been introduced to make them understand the structure that is being followed, the different areas that typically compose newspapers, how advertisements are related to the news.

- Learning of structuration and cohesion in the EFLspecifically in journalistic contexts (the traditional journalistic structure in a journalistic article from the most relevant information to less important, questions' preparation for further interview, information recompilation 
and make it contrasted or compared according to the author's strategies, for example), since $87,5 \%$ of students affirmed that their knowledge regarding journalistic structure was deficient.

- Development of two skills in EFL: written comprehension and production. Pupils were asked to consult diverse sources of information by which they had to choose quality sources for their journalistic article production. In this sense, pupils needed to read different journalistic articles and journalistic references, write down the main ideas and create their journalistic article (written production). Consequently, written comprehension was connected to written production, since comprehension was indispensable for further written production.

- Learning about the digitalization of the English language. It refers to how pupils can use digital tools for communication and collaboration to generate products in which the English language is being applied. The use of the foreign language needs to be adapted according to the platforms used for communication and collaboration, thus students can understand how language is used and constructed in digital environments (loss of non-verbal communication, more necessity to clarify, the recommendation of using simple constructions to make the virtual communicative process easier). Although $87,5 \%$ of students recognized how to use communicative and collaborative forms for academic issues, they claimed that English has been poorly used in these virtual platforms for collaborative and cooperative reasons.

- To be able to make distinctions between the descriptive and persuasive uses of English in this context, as well as to use objective and subjective genres constructions.

\subsection{Assessment}

To assess students' degree of assimilation of the objectives mentioned previously, a rubric was created. It contained, from an objective perspective, a gradual development of skills and knowledge that was taught and learned during this learning situation. 
Table 1: Rubric for Social Task Evaluation

\begin{tabular}{|c|c|c|c|c|}
\hline $\begin{array}{l}\text { Aspects of } \\
\text { evaluation }\end{array}$ & F- D & $\mathbf{C}$ & B & $\mathbf{A}$ \\
\hline $\begin{array}{l}\text { Utilization of } \\
\text { new uses of } \\
\text { English in the } \\
\text { journalistic } \\
\text { article } \\
\text { production }\end{array}$ & $\begin{array}{l}\text { The student } \\
\text { demonstrates a } \\
\text { constant need or } \\
\text { support for the } \\
\text { journalistic } \\
\text { article } \\
\text { production. } \\
\text { He/she is unable } \\
\text { to apply the } \\
\text { structure studied } \\
\text { for } \\
\text { communicative } \\
\text { reasons. }\end{array}$ & $\begin{array}{l}\text { The student can } \\
\text { use the uses of } \\
\text { English, although } \\
\text { he/she needs } \\
\text { some support } \\
\text { sometimes. There } \\
\text { are mistakes, } \\
\text { although they are } \\
\text { not very } \\
\text { important. }\end{array}$ & $\begin{array}{l}\text { The student is } \\
\text { capable to use the } \\
\text { structures studied; } \\
\text { they are adequately } \\
\text { applied in the } \\
\text { social task but few } \\
\text { mistakes (not } \\
\text { relevant) can be } \\
\text { found. The certain } \\
\text { guide is needed. }\end{array}$ & $\begin{array}{l}\text { The student is } \\
\text { capable to } \\
\text { develop and apply } \\
\text { the uses of } \\
\text { English without } \\
\text { any support or } \\
\text { guidance. He/she } \\
\text { does not commit } \\
\text { any mistake. }\end{array}$ \\
\hline $\begin{array}{l}\text { Cohesion and } \\
\text { coherence in } \\
\text { the written } \\
\text { production }\end{array}$ & $\begin{array}{l}\text { The student does } \\
\text { not connect } \\
\text { ideas, he/she is } \\
\text { not capable to } \\
\text { structure the } \\
\text { text. Information } \\
\text { is unclear and } \\
\text { unproperly } \\
\text { presented. }\end{array}$ & $\begin{array}{l}\text { The student } \\
\text { demonstrates a } \\
\text { certain connection } \\
\text { between the ideas } \\
\text { presented. } \\
\text { Although certain } \\
\text { support is needed, } \\
\text { he/she can } \\
\text { structure the text } \\
\text { and the } \\
\text { information can } \\
\text { be understood, } \\
\text { although there are } \\
\text { certain parts } \\
\text { unclear. }\end{array}$ & $\begin{array}{l}\text { The pupil is } \\
\text { capable to connect } \\
\text { most of the } \\
\text { different ideas } \\
\text { presented, certain } \\
\text { support is needed, } \\
\text { and he/she can } \\
\text { structure properly } \\
\text { and the main parts } \\
\text { of the text, } \\
\text { presenting a few } \\
\text { mistakes. }\end{array}$ & $\begin{array}{l}\text { The pupil utilizes } \\
\text { different } \\
\text { strategies to } \\
\text { connect ideas and } \\
\text { information } \\
\text { without guidance, } \\
\text { either support. } \\
\text { The text is highly } \\
\text { structured, and } \\
\text { information is } \\
\text { clearly and well } \\
\text { presented. }\end{array}$ \\
\hline $\begin{array}{l}\text { Information } \\
\text { selection }\end{array}$ & $\begin{array}{l}\text { Poor } \\
\text { information has } \\
\text { been selected. } \\
\text { He/she has not } \\
\text { selected and } \\
\text { read a } \\
\text { considerable } \\
\text { number of } \\
\text { sources; poor } \\
\text { quality sources } \\
\text { utilized. }\end{array}$ & $\begin{array}{l}\text { Certain } \\
\text { information } \\
\text { selected has been } \\
\text { used; there is an } \\
\text { acceptable } \\
\text { number of } \\
\text { sources consulted } \\
\text { and their quality } \\
\text { is acceptable. }\end{array}$ & $\begin{array}{l}\text { Different sources } \\
\text { are utilized for the } \\
\text { written production. } \\
\text { The pupil has read } \\
\text { academic sources, } \\
\text { although certain } \\
\text { guidance has been } \\
\text { needed for its } \\
\text { selection and more } \\
\text { sources could have } \\
\text { been used. }\end{array}$ & $\begin{array}{l}\text { The student has } \\
\text { selected a great } \\
\text { variety of } \\
\text { academic sources } \\
\text { without guidance } \\
\text { or support. He/she } \\
\text { has been able to } \\
\text { select the most } \\
\text { important } \\
\text { information to } \\
\text { utilize it for the } \\
\text { social task. } \\
\text { He/she } \\
\text { demonstrates }\end{array}$ \\
\hline
\end{tabular}




\begin{tabular}{|c|c|c|c|c|}
\hline & & & & $\begin{array}{l}\text { great strategies } \\
\text { for quality } \\
\text { information } \\
\text { selection. }\end{array}$ \\
\hline $\begin{array}{l}\text { Use of } \\
\text { persuasive } \\
\text { uses }\end{array}$ & $\begin{array}{l}\text { The pupil has } \\
\text { not utilized uses } \\
\text { of English of } \\
\text { conviction; } \\
\text { he/she needs } \\
\text { constant help for } \\
\text { this uses' } \\
\text { constructions; } \\
\text { the pupil is } \\
\text { incapable to use } \\
\text { these structures } \\
\text { for } \\
\text { communicative } \\
\text { reasons. }\end{array}$ & $\begin{array}{l}\text { The pupil has } \\
\text { used persuasive } \\
\text { uses of English, } \\
\text { although constant } \\
\text { help has been } \\
\text { needed. Also, } \\
\text { he/she uses these } \\
\text { structures for } \\
\text { communicative } \\
\text { reasons; mistakes } \\
\text { can be found, but } \\
\text { not relevant ones. }\end{array}$ & $\begin{array}{l}\text { The student applies } \\
\text { these uses of } \\
\text { persuasive uses of } \\
\text { conviction; certain } \\
\text { guidance has been } \\
\text { necessary. Few } \\
\text { mistakes can be } \\
\text { read, not relevant. }\end{array}$ & $\begin{array}{l}\text { The student has } \\
\text { been able to use } \\
\text { persuasive uses in } \\
\text { the English } \\
\text { language without } \\
\text { guidance or } \\
\text { support. He /she } \\
\text { has developed } \\
\text { these structures } \\
\text { making no } \\
\text { mistakes and } \\
\text { demonstrating a } \\
\text { high } \\
\text { communicative } \\
\text { application. }\end{array}$ \\
\hline $\begin{array}{l}\text { Cooperation } \\
\text { and } \\
\text { collaboration } \\
\text { in the social } \\
\text { task } \\
\text { production }\end{array}$ & $\begin{array}{l}\text { The pupil does } \\
\text { not perform } \\
\text { his/her role and } \\
\text { his/her } \\
\text { constituent } \\
\text { functions during } \\
\text { the social task } \\
\text { virtually; he/she } \\
\text { adopts a passive } \\
\text { position and } \\
\text { does not apply } \\
\text { the strategies } \\
\text { required when } \\
\text { collaborating. } \\
\text { The English } \\
\text { language is not } \\
\text { used for } \\
\text { collaborative } \\
\text { and cooperative } \\
\text { reasons or it is } \\
\text { poorly utilized } \\
\text { in virtual } \\
\text { platforms. }\end{array}$ & $\begin{array}{l}\text { The pupil applies } \\
\text { his/her role } \\
\text { during the } \\
\text { cooperative and } \\
\text { collaborative } \\
\text { virtual process, } \\
\text { although more } \\
\text { responsibility is } \\
\text { necessary. He/she } \\
\text { cooperates and } \\
\text { collaborates } \\
\text { adequately using } \\
\text { the English } \\
\text { language, } \\
\text { although there is } \\
\text { still a } \\
\text { considerable } \\
\text { exposition of the } \\
\text { mother tongue. }\end{array}$ & $\begin{array}{l}\text { The pupil is } \\
\text { capable to exercise } \\
\text { his/her function } \\
\text { with notable } \\
\text { responsibility. } \\
\text { He/she uses } \\
\text { strategies to } \\
\text { cooperate and } \\
\text { collaborate } \\
\text { virtually using } \\
\text { English; certain } \\
\text { mother tongue } \\
\text { references can be } \\
\text { noticed. }\end{array}$ & $\begin{array}{l}\text { The pupil is } \\
\text { capable to } \\
\text { exercise his/her } \\
\text { functions with a } \\
\text { high degree of } \\
\text { responsibility and } \\
\text { commitment. } \\
\text { He/she uses the } \\
\text { English language } \\
\text { for any } \\
\text { cooperative and } \\
\text { collaborative } \\
\text { process, no } \\
\text { mother tongue } \\
\text { references are } \\
\text { seen. His/her } \\
\text { strategies for the } \\
\text { communicative } \\
\text { and collaborative } \\
\text { process are very } \\
\text { well developed } \\
\text { and performed. }\end{array}$ \\
\hline
\end{tabular}

(Source: Own production) 


\section{Results}

From a generic perspective, students have been observed taking into account their written skills throughout written comprehension and written production of the newspapers' productions. This project has allowed a new practice on new structures and uses of English, as well as the adaptation of EFL in digital learning contexts. Because of the teaching-learning situation provoked by the international pandemic, students have elaborated a project in a digital environment, thus the learning of the objectives mentioned before having been adapted according to the circumstances, needs of the students and their linguistic level.

\section{What do doctors think about this pandemic?}

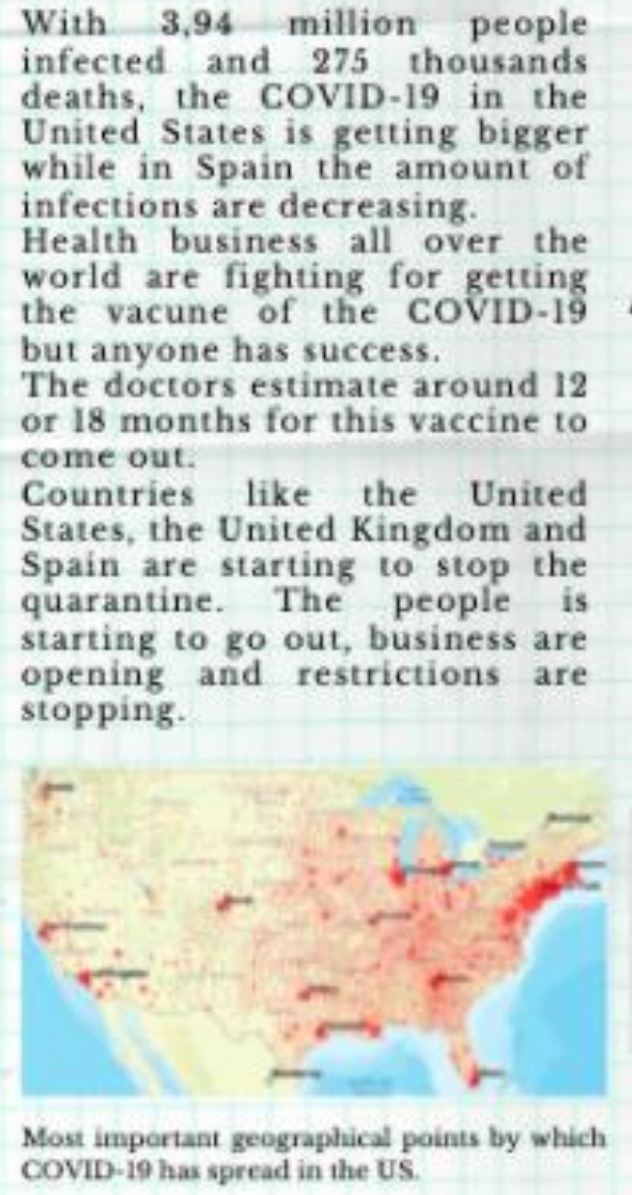

With 3,94 million people infected and 275 thousands deaths, the COVID-19 in the United States is getting bigger while in Spain the amount of infections are decreasing. the vacune of the coviD-19 but anyone has success.

The doctors estimate around 12 or 18 months for this vaccine to come out.

Countries like the United States, the United Kingdom and Spain are starting to stop the quarantine. The people is starting to go out, business are stopping.
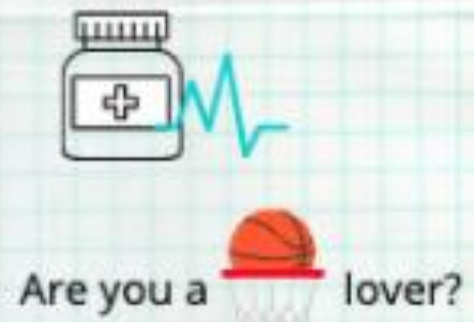

You should have the new Nike Air Jordan!! But don't worry if you can't go outside, find them in our web! All the money will be donated to the hospitals for helping infected by COVID- 19 .

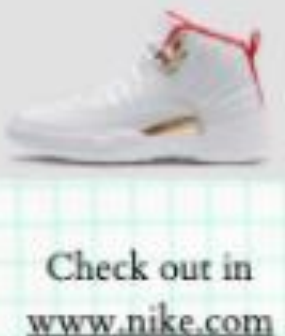
www nike.com

Figure 1: Journalistic article Developed by a Student about the COVID-19 Pandemic (Source: Own creation) 
This figure allows the analysis of the informational approach that students are applying using consulting, contrasting and verifying informational sources. There is also a sense of sociocultural knowledge in the foreign language that is created when talking about a different country: The United States of America, in this case. Moreover, communicative functions such as persuasion have been produced by the advertisement that can be seen next to the news. Students have been able to apply persuasive uses in an audio-visual application of the language, and they have been able to combine news and advertisements according to the topic treated. There is a difference in the register applied in the journalistic article from the advertisement. The journalistic article is characterized by the use of a formal register of the English language, whereas the advertisements show up an informal reference to the audience.

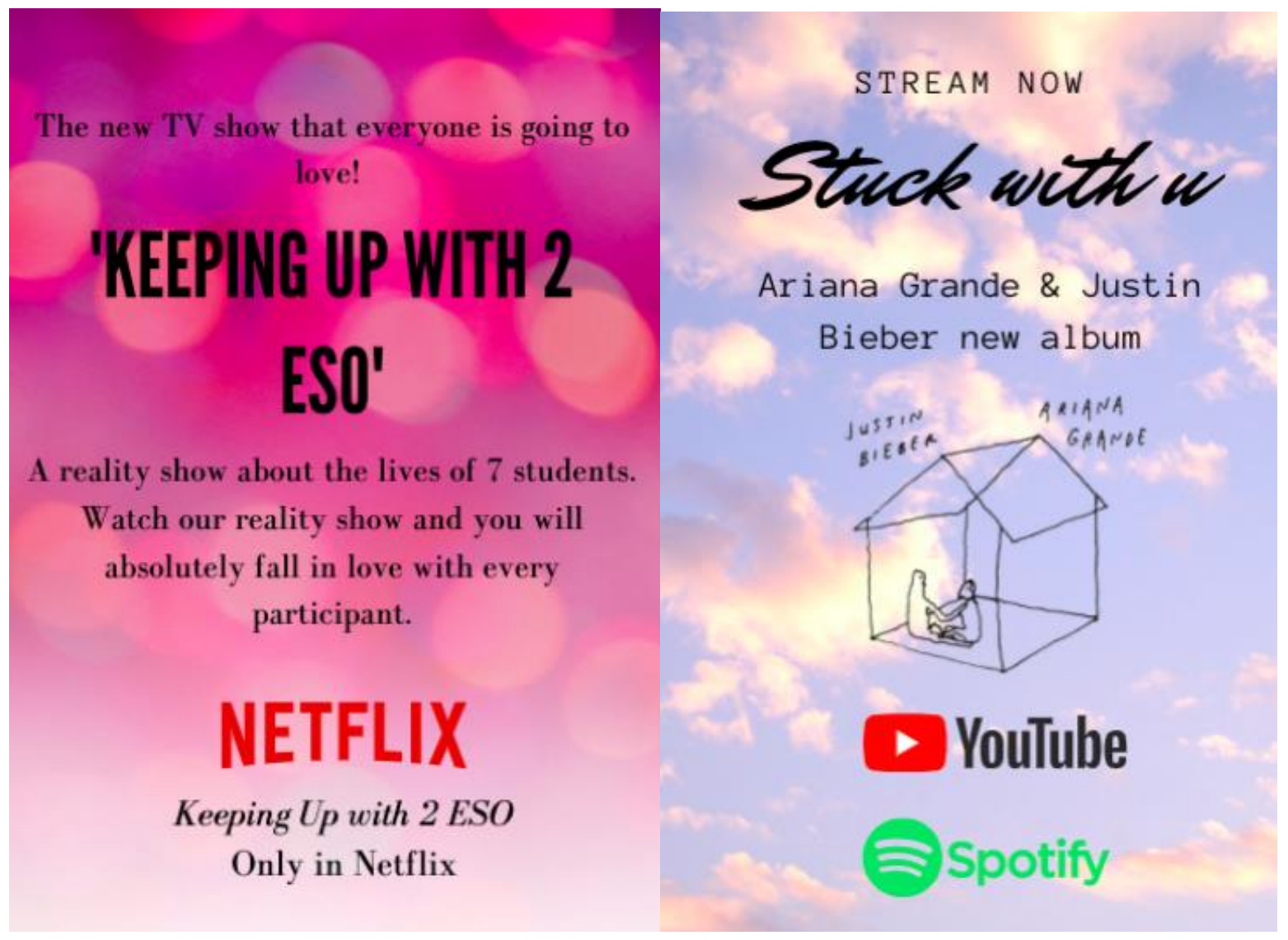

Figures 2 and 3: The Creation of Persuasive Uses by Advertisements (Source: Own creation)

Through these figures, it can be seen how students apply the persuasive uses using EFL: direct and simple constructions and playing with audiovisual productions of the English language. In this sense, students are trying to catch up audience's attention by creating audiovisual productions of English for persuasive uses in digitalized journalistic productions. 


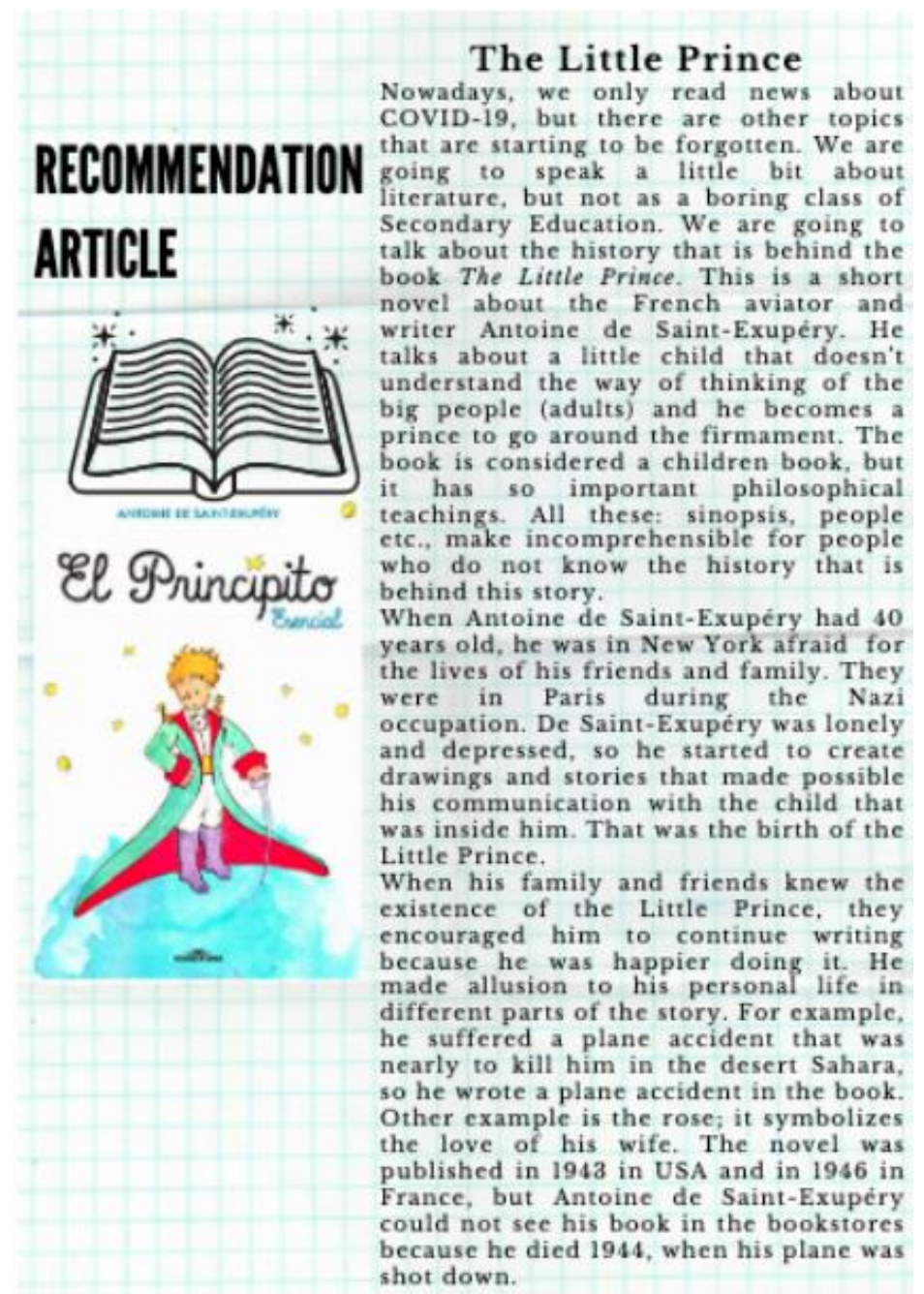

Figure 4: Journalistic Article Created for the Cultural Section

(Source: Own creation)

The intercultural competence has been also fostered through creating different sections belonging to a prototypical newspaper, such as the cultural area. In this case, literature has been introduced as a resource for reflection and recommendation for the public. By this type of projects, pupils are not only developing cultural and linguistic knowledge, but they are also taking a literacy piece in which the original language and sociocultural contexts that do not necessarily belong to English-speaking countries. In this sense, pupils' have been able to recognize that English can be utilized to express their ideas and to get to know other cultural codes and productions through speaking in English. Consequently, students have assimilated the idea of English as a lingua franca for the understanding of other sociocultural contexts. 


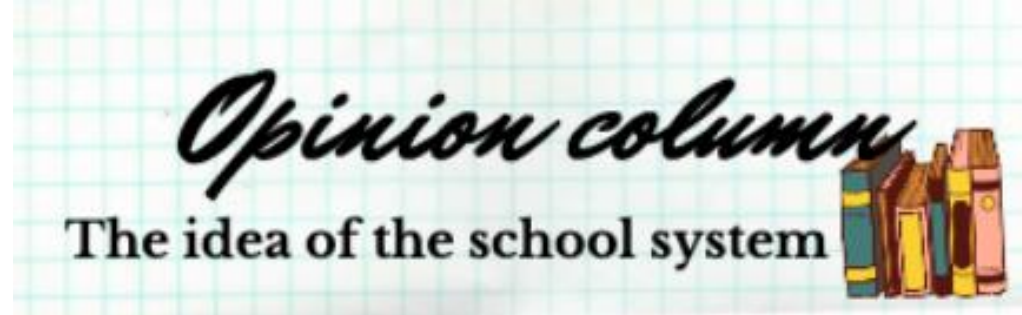

Today I will talk about the idea of the educational system after the coronavirus. This idea says that in one class, it can only be 15 pupils, when now the classes have around 28 pupils. And one part of the class goes to the school one week meanwhile the other one part has virtual class and the following week, the process is vicerversa.

I think that this idea is terrible because a lot of parents do not have time for staying home with their children. They must go to work and have no money for paying a babysitter. And the parents with the little children will have to be the teacher because they do not have the autonomy for studying.

Other problem is that not all the children have the same things, this is a problem if they want to study in their homes.

In my opinion, if this idea continues, the school should have more teachers so the industry could raise again to the time of work for the people that have family.

Personally, this idea could go good but only if we look for more and look for alternatives for the families with bad situations.

Figure 5: Opinion Column Produced by One Student (Source: Own creation)

Although subjective constructions (uses of English talking about opinions, perspectives and points of view) was not studied during this learning situation, students were interested in getting to experience these constructions and, for this reason, they have developed an opinion column based on learning by discovery. In this sense, it was a new environment that was not initially planned but finally approached due to pupils' motivations and wills to experience the different parts that compose a journalistic production, i.e., a newspaper. As a consequence, students could learn how to develop argumentative references by introducing themselves to the subjective production of the language. They have been able to progress, not only from a linguistic perspective but also metacognitive, by the sense of reflection they are producing this opinion column upon educative solutions during the pandemic COVID-19. 


\section{"I'm Canarian, I have travelled abroad and I have never seen the wall many talk about"}

\begin{abstract}
Last month Zaira Méndez was interviewed in our newspaper She was asked about life quality in the Canary islands and her traveling experiences. She recognized to be asked by Spaniards about an apparent wall that is drawn in geographical maps in the Canary islands She states.
\end{abstract} Have you ever been asked for that wall?
Ihave been asked about such a wall If you
are referning to thot small fictional square,
it is imposible to build a wall thot big.
becouse you know, too deep into the ocean,
it is just o line wniten in the mops.

What would you tell to those who believe in that wall?

The boars have superpowers or the wall doesn' exist becouse I have travelled by boot and ive never seen thot
"I'm Canarian, I hove travelled abroad and I have never seen the wall many Spaniards talk about. Tve crossed the Atlantic Ocean and I have never seen the wall, I think it doesn't exist. I just can't believe that people think there is a wall right there."

So what is the origin of this wall?

The origin of the line is a strategy to make the islands closer to rest of Spain when they want to treor the nation as a whole. The wall is a total reference that the geographical location of the Canary islands is langer far oway
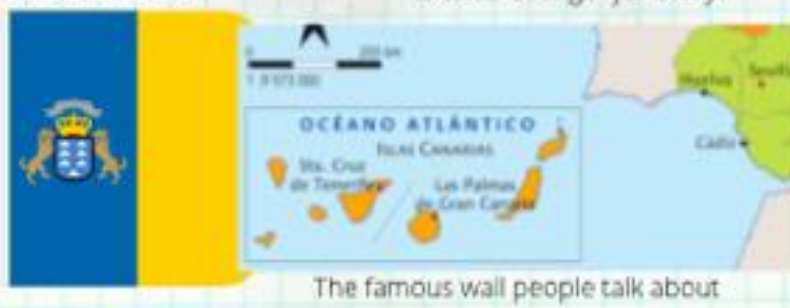

Figure 6: Interview Section

(Source: Own creation)

This selected topic for the interview is related to their experiences and circumstances they live; they have considered interviewing a civil person who is Canarian, like them, to represent the false belief that there is a physical wall in the middle of the ocean that covers the Canary Islands. There was a previous production of the possible questions, a debate among the most relevant questions to be asked and later on, the interview took place. There has been a holistic approach of several skills simultaneously (written production, oral interaction, oral comprehension) in this task. Characterized by its humour, pupils have experienced an oral interview in which they had to transform eventually to the written form for its contribution in the newspaper. From a communicative perspective, students have been able to experience questions selections, taking the 
most relevant ideas for the text production, dialogues' development, oral text summarization and the literation typically seen in this section.

\section{Horoscopes Section}

\section{Aquarius}

You will start living in a boat Regarding personal projects, you will build a pool in the forest. You will move to india and there you will find your real love this month but your friends wall hate him/her Later on you will divorce and nobody else will love you again.

\section{Pisces}

You will be a singer next month, You wil marry Kylie Jenner and you will have a baby called Sumny. Storny will hate you You will start living in a pool and you will have a fish as a pet.

\section{Aries}

You will start an enterprise in which you will waste a lot of money, Be careful You will become a model You will be pregnant or you will be father of twins. You will mowe to Bilbao

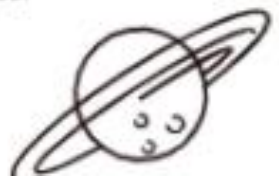

\section{Taurus}

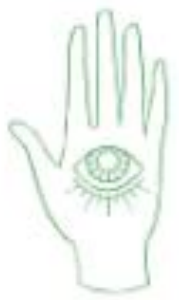

You will be in love and you will marry and also have more than 3 babies. But you will have the work that you hate You will be depressive because you hate your life but the person that you love will help you and your babies will be the best scientists of the history

\section{Gemini}

You will discover that you have an unknown twin that is Malaysian. You will get married and you will go to a party, you will have 10 babies and you won't have your PhD.

\section{Cancer}

You will confess your feelings to the person that you love by a video conference and he or she wil meet you in the McDonald's to eat Mc Chicken with you and he or she will be your boyfriend or girfriend You will get married with him or her and you will have 3 babies. You will study Chemistry at the university and you will live in Chile

Figure 7: Predictions

(Source: Own creation)

During this last section, pupils have elaborated horoscopes' predictions to put on practice predictions. Pupils have been learning these constructions during the previous learning situation. For this reason, the horoscope section was introduced as an aim to reinforce the assimilation of predictive constructions in EFL. It can be also seen how pupils still keep the persuasive uses because of the direct reference to the audience. 


\section{Debate}

Results were highly positive, since $87,5 \%$ of pupils demonstrated a notable and/or outstanding learning of vocabulary, whereas the remaining $12,5 \%$ showed a generic use of the vocabulary selected. Moreover, $75 \%$ of pupils utilized and applied the uses of English introduced in the research and the $87,5 \%$ was able to use persuasive uses in the foreign language as revision linguistic uses of English. 62,5\% of students recognized to understand the journalistic structure and applied it correctly in the learning situation. Also, revision uses of English about the future has been applied and $87,5 \%$ of students successfully used it during the learning situation in the Horoscope section.

\section{Conclusions}

This project has demonstrated a process of learning but also the acquisition of the EFL by reproducing realistic and communicative models of the language. It has been a learning situation that has made students learn and understand about the pandemic circumstances and their adaptation to a new digitalized educational system, i.e., e-learning. To do it so, cooperative and collaborative methodologies have been applied for the construction of these objectives.

From a linguistic perspective, pupils have practised on objective structures of the language, utilizing these uses of English simultaneously with persuasive uses of the English language. They have also introduced themselves into subjective productions of the language by their own will to learn and experience. Pupils have also learned the different areas that compose a newspaper and the interdependence relations between objective and subjective journalistic productions. Moreover, pupils' use of communicative skills in written contexts have evolved their strategies about written production and comprehension.

Students have also developed multicultural learning throughout the creation of international news and treating foreign literacy pieces. Implicitly, the study of socio-cultural processes and events is studied and the position of English as a lingua franca is assimilated. Students get to understand that language and culture cannot be separated; English is a medium of communication even for those cultures in which the native language is not English.

From a communicative and journalistic perspective, models and resources have been correctly utilized learning the different parts and processes required for the creation of a newspaper. This activity has fostered experimentation of this foreign language using formal and 
informal registers and literacy elements such as hyperbole, interpretation, data analysis, contrast and comparison, among the most important linguistic references seen.

Digitally, this activity has been an integrated learning of linguistics, culture and communicative tools in a journalist context: because of the pandemic situation, pupils and teachers have been forced to adapt themselves to use ICT as mediums for learning, cooperation and collaboration. ICT have become indispensable tools for the learning process of any subject. Moreover, the current bilingual programs developed in many schools have also evolved the English language as the linguistic tool in the educational environment. In this sense, both ICT and EFL are both applied in this learning situation for their learning and especially assimilation because of their relevant role in other disciplines' study. Also, because of the main topic that has been selected for vocabulary learning (COVID-19 pandemic), pupils have demonstrated certain comprehension and have developed their argumentation about a topic they have been previously informed by reading, consulting quality information and applying it to communicative contexts.

\subsection{Problems Observed and Further Studies}

It must be taking into account that this investigation was developed in a small group, thus results can be subject to modification due to the small composition of the focus group. Technological reasons have also affected the social task development since there were situations in which the different virtual platforms used for collaboration and cooperation did not work due to the Wi-Fi connection. This handicap surely affected the efficiency during the cooperative and collaborative processes. Moreover, it must be mentioned the lack of preparation of the digital sources, since the socio-economic circumstances of confinement were not expected, thus the educational system did not prepare itself for virtual teaching and learning.

\section{REFERENCES}

Akdemir, A. S., Barin, M., \& Demiroz, H. (2012). Broadsheet English: teaching speaking through newspaper journalistic articles. Procedia-Social and Behavioral Sciences, 46, 3967-3971. https://doi.org/10.1016/j.sbspro.2012.06.180

Baumgardner, R. J. (1987). Utilizing Pakistani newspaper English to teach grammar. World Englishes, 6(3), 241-252. https://doi.org/10.1111/j.1467-971X.1987.tb00204.X 
Gómez, P. G. (2003). Los titulares de prensa en el aula de español lengua extranjera: propuestas didácticas. In Medios de comunicación y enseñanza del español como lengua extranjera: actas del XIV Congreso Internacional de" ASELE", Burgos, Universidad de Burgos. (pp. 654-665). Universidad de Burgos.

Hull, T. (2019). Communicative Testing in the EFL Classroom. PUPIL: International Journal of Teaching, Education and Learning, 3(3), 01-14. https://doi.org/10.20319/pijtel.2019.33.0114

Laadem, M. (2017). E- Learning Integration in Higher Education: Focus on Moroccan Departments of English PUPIL: International Journal of Teaching, Education and Learning, 1(2), 115-133. https://doi.org/10.20319/pijtel.2017.12.115133

Labarrete, R. A. (2019). Reading Comprehension Level and Study Skills Competence of the Alternative Learning System (ALS) Clientele. PUPIL: International Journal of Teaching, Education and Learning, 3(1), 220-229. https://doi.org/10.20319/pijtel.2019.31.220229

López, A. M. (1998). Transversabilidad y medios de comunicación social en la enseñanza de la Lengua y Literatura en Secundaria. Revista interuniversitaria de formación del profesorado, (32), 179-190.

Manasrah, M. A., \& Al-Khawaldeh, K. (2014). The effect of using journalistic texts on the development of vocabulary of English as a foreign language for university students. International Journal of Humanities and Social Science,4(11), 131-135. Retrieved from: http://www.ijhssnet.com /journals/Vol_4_No_11_1_September 20 14/13.pdf. Accessed on $10^{\text {th }}$ August 2020.

Mittal, R. (2014). Role of newspaper in English language learning. International Journal of Research, 1(6), 689-693. Retrieved from: $\underline{\text { http://citeseerx.ist.psu.edu/viewdoc/download?doi=10.1.1.680.6439\&rep }=\text { rep1\&type }=\text { pdf }}$ . Accessed on 12th August 2020.

Peris, M. (2001). Textos, variedades lingüísticas y modelos de la lengua en la enseñanza del español como lengua extranjera. Carabela, (50), 103-137.

García Platero, J. M. (2000). El corpus periodístico en la enseñanza del español: ¿reflejo de la norma? En ¿Qué español enseñar?: norma y variación lingüísticas en la enseñanza del español a extranjeros: actas del XI Congreso Internacional ASELE, Zaragoza 13-16 de septiembre de 2000 (pp. 359-364). Asociación para la Enseñanza del Español como Lengua Extranjera. 
Oroujlou, N. (2012). The importance of media in foreign language learning. Procedia: Social and Behavioral Science, 51, 24-28. https://doi.org/10.1016/j.sbspro.2012.08.113

Reaser, J. (2010). Using media to teach about language. Language and Linguistics Compass, 4(9), 782-792. https://doi.org/10.1111/j.1749-818X.2010.00237.X

Shakibaei, G., Namaziandost, E., \& Shahamat, F. (2019). The effect of using authentic texts on Iranian EFL learners' incidental vocabulary learning: The case of English newspaper. International Journal of Linguistics, Literature and Translation (IJLLT), 2(5), 422-432. https://doi.10.32996/ijllt.2019.2.5.47 